\title{
PERANAN KOPERASI SEBAGAI BENTUK IMPLEMENTASI EKONOMI PANCASILA DI ERA DIGITAL
}

\author{
Wiwi Warsiati $^{1)}$, Tiris Sudartono ${ }^{2)}$, Riana Dewi ${ }^{3)}$ \\ ${ }^{1}$ Administrasi Keuangan, Politeknik Piksi Ganesha \\ email: wiwiwarsiati@gmail.com \\ ${ }^{2}$ Komputerisasi Keuangan, Politeknik Piksi Ganesha \\ email: tiris.sudartono@gmail.com \\ ${ }^{3}$ Administrasi Keuangan, Politeknik Piksi Ganesha \\ email: rdewwi17@gmail.com
}

\begin{abstract}
The role of cooperatives on the economy in Indonesia is still low due to low performance and cooperative governance not based on good cooperative governance. Cooperatives find it difficult to develop because they are unable to keep up with changes in the digital era. Pancasila economics was explored and built on the values adopted in Indonesian society which put forward the principles of humanity, nationalism, and cooperative democracy demanded to make a transformation so as not to be left behind by members and society. The Kopti cooperative consists of entrepreneurs who know tempeh has the potential to make changes because the quality of human resources is better than other cooperatives. Cooperatives must build creative and innovative characters for cooperative mobilizers through education and training. Cooperative in the digital era by implementing Information Networks, e-commerce online stores that have advantages such as Cost Savings, Potential Income, Extensive sales, Ease in targeting customers, Facilitating the process when orders increase
\end{abstract}

Keywords: cooperatives, digital era

\section{PENDAhUlUAN}

Dengan dimulainya era revolusi industri ke- 4, Keberadaan koperasi di Indonesia berdasarkan pada Undang Undang Koperasi No 25 Tahun 1992 pasal 1 ayat 1 yaitu : "Koperasi adalah badan usaha yang beranggotakan orang-seorang atau badan hukum koperasi dengan melandaskan kegiatannya berdasarkan prinsip koperasi sekaligus sebagai gerakan ekonomi rakyat yang berdasar atas asas kekeluargaan". Tujuan koperasi sesuai yang tercantum pada pasal 3 yaitu : "Koperasi bertujuan memajukan kesejahteraan anggota pada khususnya dan masyarakat pada umumnya serta ikut membangun tatanan perekonomian nasional dalam rangka mewujudkan masyarakat yang maju, adil, dan makmur berlandaskan Pancasila dan Undang Undang Dasar 1945".

Koperasi merupakan organisasi ekonomi otonom, yang terbentuk karena adanya kelompok individu, bersatu untuk mendirikan koperasi. Dengan memperhatikan hal tersebut dapat dibedakan koperasi dengan bentuk usaha lain dari sisi keanggotaan adalah prinsif identitas ganda (dual identity), dimana anggota sebagai pemilik juga sebagai pelanggan dari koperasi. Status ini merupakan identitas anggota koperasi, dimana anggota sebagai pemilik identik dengan anggota sebagai pelanggan koperasi yang dituntut untuk memanfaatkan koperasi, hal ini akan berimplikasi luas terhadap perkembangan usaha koperasi melalui kegiatan-kegiatan yang dilakukan pada unit usahanya.

Koperasi juga mempuyai kelebihan yang menjadi kekuatan utama dalam lembaga yang tidak di miliki oleh lembaga lain baik BUMN atau lembaga swasta. Kelebihan koperasi yang pertama kekuatan sumber daya manusia, koperasi merupakan lembaga yang berasetkan manusia. Di koperasi jumlah anggota tidak di batasi. Dengan semakin bertambah anggota di dalam sebuah koperasi, maka semakin besar pula pergerakan perekonomian yang dilakukan oleh anggota. Kelebihan yang kedua adalah kekuatan pendanaan dengan kekuatan manusia yang begitu banyak tanpa ada batas yang telah menyatukan pikiran, maksud dan tujuan serta mempunyai kepentingan yang sama maka akan menghasilkan pendanaan yang luar biasa.

Kelebihan yang selanjutnya kekuatan produk, produk yang dihasilkan koperasi sudah jelas di awal pembentukan koperasi itu sendiri adalah menyatukan pikiran, maksud dan tujuan serta mempunyai kepentingan yang sama. Dengan demikian, produk yang dihasilkan akan dibahas secara bersama untuk menghasilkan produk yang dibutuhkan para anggotanya. Koperasi tanpa harus mencari 
konsumen keluar koperasi. Dunia digital merubah hidup kita dengan cara yang tidak terbayangkan. Teknologi berubah dari sesuatu yang terlihat menjadi sesuatu yang tidak terlihat, dimana kita diperkenalkan pada teknologi yang invisible seperti Internet of Things dan Cloud Computing (Kusuma, 2018).

Koperasi pada era digital harus beradaptasi dan bertransformasi dalam menghadapi lingkungan yang senantiasa dinamis. Langkah awal yang perlu dilakukan dalam transformasi koperasi adalah membangun karakter kreatif dan inovatif bagi insan penggerak koperasi. Kreatifitas mengharuskan insan koperasi dapat berpikir berbeda Insan koperasi yang harus disiapkan di era digital Dengan insan yang kreatif dan inovatif koperasi dapat memulai transformasi dirinya untuk menata organisasi dan strategi bisnisnya di era digital

Berdasarkan uraian di atas, dapat diidentifikasi permasalahan koperasi yang akan diselesaikan dalam pengabdian kepada masyarakat ini adalah belum adanya penyuluhan/sosialisasi dan pelatihan Aplikasi Koperasi dalam simpanan pinjam secara online yang diperuntukkan bagi para anggota terutama pada pengusaha tahu tempe yang kesulitan pemasaran, masalah manajemen sumberdaya manusia dan bahan baku.

Target dari pelaksanaan kegiatan pengabdian kepada masyarakat ini adalah Pertama, pemberian sosialisasi dan pengenalan Aplikasi Koperasi pada pengusaha tahu tempe. Kedua, pemberian pengetahuan dalam bentuk pelatihan penggunaan Aplikasi Koperasi berbasis Android yang digunakan untuk melakukan pencatatan dan penyusunan laporan keuganan dan mengetahui hasil sisa hasil usaha (SHU) secara online dengan cara memasarkan produksi secara konvensional, namun harus menggunakan teknologi secara digital atau sering disebut dengan pemasaran melalui internet dalam masyarakat umum disebut e-Commerce.

\section{METODE PELAKSANAAN}

Tahapan dan proses pelaksanaan kegiatan pengabdian kepada masyarakat:

1. Tahap Persiapan

a. Merancang kebutuhan pelatihan

b. Menentukan peserta dan narasumber c. Menentukan waktu dan tempat pelatihan

d. Menyiapkan materi dan akomodasi

2. Tahap Pelaksanaan Pelatihan

a. Ceramah dan diskusi

b. Pengenalan aplikasi sistem koperasi berbasis android

c. Pengenalan pemasaran online strategis Metode pelaksanaan kegiatan dengan ceramah dan diskusi interaktif serta klinikal bisnis membedah kasus permasalahan yang dihadapi oleh Kopeti. Materi disampaiakan berdasarkan data dan kondisi koperasi terkini.

\section{HASIL DAN PEMBAHASAN}

KOPTI yang beralamat di Jalan Persahabatan Raya No.10 Rawamangun Jakarta Timur Merupakan koperasi Primer yang bergerak dalam usaha Tahu dan Tempe yang mengutamakan kekuatan produk dalam kegiatan usahanya, produk yang dihasilkan koperasi KOPTI sudah jelas di awal pembentukan koperasi itu sendiri adalah menyatukan pikiran, maksud dan tujuan serta mempunyai kepentingan yang sama sesama anggotanya. Dengan demikian, produk yang dihasilkannyapun akan dibahas secara bersama untuk menghasilkan produk yang dibutuhkan para anggotanya, yang selanjutnya Koperasipun memasarkan produknya keluar area koperasi berada yaitu sekitar wilayah Jakarta Timur.

Koperasi yang modern dan maju haruslah dikelola dengan menajamen yang baik dan mengikuti kemajuan serta perkembangan ekonomi saat ini, terutama pada era digital yang segala kegitatan ekonomi di masyarakat telah menggunakan teknolgi komunikasi dan informasi dalam melakukan usahanya. Manajemen yang baik merupakan suatu proses untuk mewujudkan tujuan yang diinginkan sehingga dalam suatu organisasi perusahaan ataupun koperasi merupakan suatu alat untuk mengatur semua aktivitas dalam mencapai tujuan, tegasnya pengaturan hanya dapat dilakukan didalam suatu organisasi, sebab dalam suatu organisasi itulah tempat kerjasama, proses manajemen, pembagian kerja, koordinasi dan integrasi dilakukan untuk mencapai tujuan yang ingin dicapai. Menurut Malayu SP. Hasibuan (2001) Manajemen adalah ilmu dan seni mengatur proses pemanfaatan sumber daya manusia dan sumber-sumber lainnya secara efektif dan efesien untuk mencapai suatu tujuan tertentu.

Program-program manajemen yang dilaksanakan oleh koperasi pada dasarnya 
adalah untuk meningkatkan kepedulian anggota terhadap koperasi dan untuk memenuhi kebutuhan anggota dan programprogram koperasi itupun dirancang dan diputuskan oleh anggota, dibiayai oleh anggota dan dimodali oleh anggota juga, oleh Pengelolaan manajemen koperasi untuk dan dari anggota tersebut menurut Ropke diartikan sebagai berikut :

1. Berbicara dan bertindak atau disebut Voice;

2. Memberikan hak suara pada proses pengambilan keputusan atau disebut Vote;

3. Menyatakan keluar dari keanggotaan koperasi atau disebut exit.

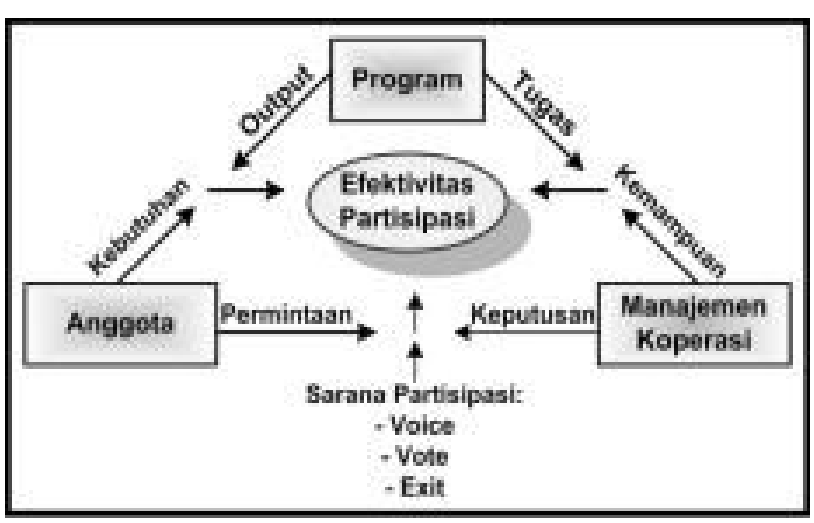

Gambar 1. The Fit Models of participation dielaborasi oleh (Ramudi Arifin 2013)

Dalam bagan tersebut juga dijelaskan bahwa manajemen koperasi berupa keikutsertaan sebab itu, anggota koperasi harus dapat memanfaatkan pelayanan yang diselenggarakan oleh koperasi anggota yang efektif dapat mencapai hasil sebagai berikut ( Jochen Ropke, 2000;48) :

1 Para anggota akan memutuskan jumlah fungsi koperasinya (fungsi tunggal atau multi fungsi/multiusaha)

2 Para anggota akan memutuskan struktur koperasinya menjadi organisasi sederhana atau lebih komplek; dan juga koperasi tersebut akan menjadi multilevel yang lebih besar (dari lembaga primer

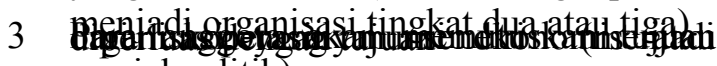
sosial politik).

Koperasi KOPTI sebagai organisasi ekonomi yang bergerak dalam produk Tahu dan Tempe tidak mengkhususkan aktivitasnya untuk memperoleh keuntungan tapi lebih mengutamakan kepentingan dan kesejahteraan anggota dalam bentuk pelayanan yang memuaskan. Hal ini karena tugas pokok koperasi adalah menunjang kepentingan ekonomi anggotanya, oleh karena itu dalam melaksanakan atau menentukan kebijakan usaha harus berdasarkan kepada kepentingan-kepentingan anggota, hal ini agar dapat meningkatkan motivasi dan meningkatkan partisipasi anggota secara efektif.

Dalam upaya meningkatkan ekonomi para anggotanya tersebut tentunya Koperasi KOPTI haruslah berupaya meningkatkan hasil produksi dan velume penjualan Tahu dan Tempe sebagai andalan produknya, untuk meningkatkan penjulan tersebut pada saat ini salah satunya adalah dengan

memanfaatkan kemajuan teknologi berupa pengelolaan keuangan koperasi dan sistem penjualan yang serba digital disamping penjulan yang selama ini dilakukan oleh koperasi secara konfensional selain itu juga agar koperasi dapat terus berperan dalam penyediaan Tahu dan Tempe di Wilayah Jakarta Timur dan sekitarnya serta memiliki daya saing maka perlu upaya-upaya untuk meningkatkan daya saing Koperasi KOPTI, antara lain:

a. Konsisten menjaga kualitas Produk

Bisnis Koperasi beruapa produk Tahu dan Tempenya sepanjang tetap konsisten menjaga kualitas produknya yang mereka pasarkan. Melakukan pembuatan standar operasional prosedur (SOP) yang jelas dalam setiap proses produksi, agar produk Tahu dan Tempe yang dipasarkan yang disampaikan memiliki kualitas atau standar mutu yang terjamin serupa.

b. Packaging produk yang menarik

Sampai saat ini packaging produk menjadi salah satu faktor pendorong bagi para calon

Konsumen untuk melakukan transaksi pembelian. Karenanya selain menjaga kualitas produk, hal lain yang perlu diperhatikan para pengelola koperasi adalah

mendesain packaging yang menarik, serta mencantumkan logo dan nama produk Tahu dan Tempe di setiap kemasan produknya.

c. Menjaga loyalitas konsumen

Memiliki banyak pelanggan setia menjadi kunci utama kesuksesan koperasi. Ketika konsumen memiliki loyalitas yang cukup tinggi terhadap produk Tahu dan Tempe diproduksi Koperasi KOPTI yang dipasarkan, maka sebagai 
Pengurus dan pengelola koperasi tak perlu khawatir ditinggalkan konsumen

Produk Tahu dan Tempe koperasi KOPTI belum signifikan memiliki daya saing yang kuat kerena terdapat beberapa kelemahan yang terdapat pada hasil produksi Tahu dan Tempe Koperasi KOPTI antara lain:

\section{Kesulitan pemasaran}

Masalah pemasaran yang umum dihadapi oleh pengelola koperasi KOPTI adalah tekanan-tekanan persaingan, baik di wilayah pemasaran Jakarta Timur dan sekitarnya maupun dari produk yang serupa buatan pengusaha-pengusaha lain yang jauh lebih berkualitas.

2 Keterbatasan Financial

Koperasi KOPTI menghadapi dua masalah utama dalam aspek finansial antara lain: modal (baik modal awal maupun modal kerja) dan finansial jangka panjang untuk investasi yang sangat diperlukan untuk pertumbuhan output jangka panjang dari produksi Tahu dan Tempe tersebut.

3 Keterbatasan Sumber Daya Manusia (SDM) Keterbatasan sumber daya manusia juga merupakan salah satu kendala serius bagi koperasi KOPTI, terutama dalam aspek-aspek kewirausahaan, manajemen, teknik produksi, pengembangan produk, control kualitas, akuntansi, teknik pemasaran, dan penelitian pasar. Semua keahlian tersebut sangat diperlukan untuk mempertahankan atau memperbaiki kualitas produk tahu dan tempe, meningkatkan efisiensi dan produktifitas dalam produksi, memperluas pangsa pasar dan menembus pasar baru.

4 Masalah bahan baku

Keterbatasan bahan baku terutama pasokan kedelai sering menjadi salah satu masalah serius bagi pertumbuhan output atau kelangsungan produksi bagi pengelola koperasi KOPTI

5 Keterbatasan teknologi

Koperasi KOPTI masih menggunakan teknologi tradisonal atau alat-alat produksi yang sifatnya manual. Keterbelakangan teknologi ini tidak hanya membuat rendahnya jumlah produksi tahu tempe dan efisiensi di dalam proses produksi, tetapi juga rendahnya kualitas produk tahu dan tempe yang dibuat. Keterbatasan teknologi disebabkan oleh banyak faktor seperti Keterbatasan modal investasi untukmenyediakan alat dan tempat yang sesuai.

Dalam upaya meningkatan kesejahteraan para anggota koperasi KOPTI melalui wadah bersama. Koperasi yang dijalankan melalui implemantasi ekonomi pancasila yang sesuai dengan perekonomian bangsa Indonesia berupa :

1. Ketuhanan Yang Maha Esa, maka Koperasi KOPTI melaksanakan kegiatan usahanya pada keyakinan dan kepercayaan tertentu, tidak membedakan suku, budaya dan bersifat sukarela, terbuka bersifat Ketuhanan ;

2. Kemanusiaan Yang Adil dan Beradab, Koperasi KOPTI mengembangkan sikap saling menghormati dan diberi hak dan kewajiban yang sama bagi seluruh anggota koperasi ;

3. Persatuan Indonesia, Koperasi KOPTI dalam persyartan keanggotaan tidak membeda bedakan agama,suku bangsa, warna kulit, jenis kelamin asal mempunyai kepentingan yang sama dan memnuhi syarat sebagai anggota, dapat menjadi anggota Koperasi KOPTI ;

4. Kerakyatan Yang Dipimpin oleh Hikmah Kebijaksanaan Dalam Permusyawaratan/Perwakilan, Koperasi KOPTI dikelola secara domokratis, pemegang kekuasaan tertinggi dari koperasi adalah Keputusan Rapat Anggota Koperasi juga setiap keputusan diambil dengan mengedepankan musyawarah untuk mufakat

5. Keadilan Sosial Bagi Seluruh Rakyat Indonesia. Koperasi KOPTI dibentuk untuk meningkatkan taraf hidup para anggotanya khususnya dan masyarakat pada umumnya diantaranya pembagian Sisa Hasil Usaha yang diberikan dengan adil sesuai dengan jasa partisipasinya kepada koperasi.

Dengan berlandasakan ekonomi pancasila tersebut, maka Koperasi KOPTI harus mampu meningkatkan kesejahteraan para anggotanya salah satunya dengan cara meningkatkan volume penjulan. Dengan perkembangan ilmu pengetahuan dan teknolgi yang pesat saat ini, meningkatkan volume penjualan tidak bisa lagi dengan cara memasarkan produksi secara konvensional namun harus menggunakan 
teknolgi secara digital atau sering disebut dengan pemasaran melalui internet dalam masyarakat umum disebut e-Commerce .Menurut Eko Indrajit (2014) e-Commerce atau electronic Commerce adalah sebagai perdegangan elektronik dimana untuk transaksi perdagangan baik mebeli maupun menjual dilakukan melalui elektronik pada jaringan internet, keberadaan e-Commerce sendiri dalam internet dapat dikenali melalui adanya fasilitas pemasangan iklan, penjulan dan service support bagi seluruh pelanggannya dengan menggunakan toko online berbentuk web yang setiap harinya beropersi selama 24 jam. e-Commerce yang diimplementasikan pada usaha koperasi Tahu dan Tempe meruapakan pertukaran informasi berbentuk transaksi binis, baik bersifat Financial maupun non Financial antara anggota koperasi dan pihak lain atau konsumen lain melalui media elektronik atau digital ( Internet dan Web). Penggunaan media elektronik ( Internet dan $\mathrm{Web}$ ) tersebut memberikan karekteristik pada e-Commerce, sehingga lebih powerful dibandingkan jika koperasi KOPTI melakukan pemasaran secara tradisional. Oleh karena e-Commerce berbasis internet atau pasar digital sehingga pada saat ini e-Commerce menjadi pasar yang sangat fleksibel dan efesien dibanding pasar tradisional atau koperasi emasarkan langsung ke pasar secara konvensional, pasar digital mampu mengurangi biaya transaksi, biaya pencarian, biaya pengiriman serta mampu secara dinamis menyesuaikan harga produk Tahu dan Tempe yang sesuai dengan kondisi pasar.

Pasar Digital memungkinakan Koperasi KOPTI untuk menjual produknya secara langsung kepada para anggotanya atau konsumen lain tanpa melalui perantara misalnya toko, warung, pengecer dan lain sebaginya dengan kata lain pasar digital memilki aksesibilitas yang tinggi karena mampu mempertemukan secara langsung antara pihak koperasi dan yang membutuhkan secara luas.

Manfaat yang dapat diperoleh oleh Koperasi jika memanfaatkan teknologi komunikasi dan informasi dalam memasarkan produknya yaitu :

1. Hemat Biaya ;

2. Potential Income;

3. Jangkauan penjulan secara luas ;
4. Kemudahan dalam menargetkan pelanggan ;

5. Memudahkan proses ketika pesanan meningkat ;

6. Kemudahan inetraksi dengan anggota sebagai pelanggan;

7. Pelanggan dan anggota tidak harus berkunjung ke toko, pasar dll.

\section{KESIMPULAN}

1. Koperasi merupakan organisasi ekonomi otonom, yang terbentuk karena adanya kelompok individu, bersatu untuk mendirikan koperasi. Dengan memperhatikan hal tersebut dapat dibedakan koperasi dengan bentuk usaha lain dari sisi keanggotaan adalah prinsif identitas ganda (dual identity), dimana anggota sebagai pemilik juga sebagai pelanggan dari koperasi.

2. Dalam upaya meningkatkan ekonomi para anggotanya koperasi harus memilki daya saing produk dengan cara konsisten menjaga kualitas produk, packaging produk yang menarik dan menjaga loyalitas konsumen.

3. Dalam mengatasi kelemahan yang dimilki koperasi dalam bidang Kesulitan pemasaran, keterbatasan financial, keterbatasan sumber daya manusia, keterbatasan bahan baku dan keterbatasan teknologi, maka koperasi harus melakukan usaha koperasi dengan memanfaatkan teknologi informasi dan komunkasi atau keperasi dikelola dengan menggunakan teknologi digital.

4. Media yang sesuai dengan perkembangan jaman adalah koperasi melakukan kegiatan dengan $e$ commerce selain cara konvensial yang selama ini dilakukan.

\section{REFERENSI}

Henel, A. 2005. Organisasi Koperasi. Graha Ilmu. Yogyakarta

Indrajit, R.E. 2014, Electronic Commerce, Graha Ilmu. Jakarta.

Ramudi, A.2006. Ekonomi Koperasi.IKOPIN Press. Jatinangor

Ramudi, A. 2013. Koperasi sebagai Perusahaan. IKOPIN Press. Jatinangor.

Tjiptono, F dan Chandra., 2012, Strategi Pemasaran. Andy Offset. Yogyakarta. 